\title{
IMAGINED ISLAMIC SOCIETIES AND THE ROLE OF ULEMA IN CONTEMPORARY INDONESIA
}

\author{
Choirul Mahfud \\ Sepuluh Nopember Institute of Technology \\ Keputih, Sukolilo, Surabaya, Jawa Timur 60111 \\ E-mail: choirul.mahfud@its.ac.id
}

\begin{tabular}{c|c|c}
\hline Received: & Revised: & Approved: \\
$25 / 07 / 2019$ & $10 / 08 / 2019$ & $28 / 09 / 2019$ \\
\hline
\end{tabular}

DOI: http:// dx.doi.org/10.32332/akademika.v24i2.1567$$
\text { (c) (7) (2) }
$$

Imagined Islamic Societies And The Role Of Ulema In Contemporary Indonesia Licensed Under a Creative Commons Attribution-ShareAlike 4.0 International License
\end{abstract}

\begin{abstract}
This article focuses discuss questions about how the role and contribution of ulema in the social life of religion in Indonesia. Also, how is the typology and characteristic of ulema in contemporary Indonesia. Sociologically, ulema is part of the most important topics in the study of religious institutions in the Islamic world, including when speaking about Islam in Indonesia. Ulema is also juxtaposed with umara. In this case, the position and role of the ulema are like an "informal" leader in a nation for Muslim Societies. In Indonesia, ulema has a central role in religious and state life to shape the imagined Islamic societies, such as Nusantara Islam and others. From time to time, ulema has made major contributions from before until after independence to the present. This is evident from the historical track record of ulema institutions in Indonesia. From Sabang to Merauke island, the term of ulema has an interesting nickname. For example, there are many other names of ulama like Kiai (Java), Tengku (Aceh), Ajengan (Sundanese), Buya (Minangkabau), Sheikh (North Sumatra), Tuan Guru (Lombok, West Nusa Tenggara and Kalimantan).
\end{abstract}

Keywords: Ulema, Indonesian Islam, and Imagined Islamic Societies 


\section{A. Introduction}

Antonio Gramsci (1971) once stated that "All men are intellectuals, but not all men have in society the function of intellectuals."1The statement of the great thinker from Italy was indeed not addressed directly to the scholars or ulema. But the term "intellectuals" used by Gramsci can be understood as "ulama". Because, "ulama" also has a big role for the Muslim community in the world, including in Indonesia.

In this discussion, some people judge that scholars have similarities with intellectuals. Through his monumental book, La Trahison Des Clercs (1927), Julian Benda gave several intellectual accounts. Among other things, an intellectual is a warrior of truth and justice, persevering and enjoying the field he is in, not riding ambitious material and momentary interests, daring to get out of his den to protest injustice and speak out the truth, despite the expensive risks, and therefore he is not afraid of prison or hard life. Therefore, Julian Benda, "La Trahison des Clercs", advised that intellectuals must be those whose activities are not basically to achieve practical goals.

In his book "La Trahison des Clercs", Buya Syafii Maarif considered that Julian Benda connected the intellectuals not only to the priests who were good at writing, to the French literary group at the time his La Trahison des Clercs was published in 1927 to distinguish it from the latin.2In the French dictionary, said Syafii, the words of Clercs do not only contain spiritual meanings but also mean learned people or scholars in general. Therefore, Syafii interprets the term intellectuals who are meant by Benda, not ordinary educated groups, because big names like Descartes, Vico, Spinoza, Renan, Hegel, Goethe, Nietzsche, and many others in modern European history are mentioned on the pages of modern Europe, the work of $\mathrm{La}$ Trahison above. In the context of Indonesian Islam, we can also include most of the ulama's figures and others as intellectuals who have great influence, role, and services for this country. ${ }^{3}$

Moreover, history has also noted that ulema are often juxtaposed with Umara. Where the position and role of the ulema are like an "informal"

1 Gramsci, Antonio. Selection from the Prison Notebooks. New York: International Publisher, 1971.

2 Maarif, Ahmad Syafii, Pengkhianatan Kaum Intelektual Indonesia: Perspektif Kebudayaan, Naskah Pidato Kebudayaan, 22 November 2005, di Graha Bhakti Budaya-Taman Ismail Marzuki, Jakarta.

3 Jamhari, "New Trend of Islamic Education in Indonesia," Studia Islamika, Vol 16, No 2, (2009). Krisdiyanto, Muflikha, Sahara, Mahfud, C., "Sistem Pendidikan Pesantren dan Tantangan Modernitas". Tarbawi: Jurnal Ilmu Pendidikan, 15 (1), 2019: 11-21. 
leader in a country for the people under certain conditions. In Indonesia, ulama have a position and role that is not small from before until after independence until now. This is evident from the historical track record of ulama institutions in this country. From Sabang to Merauke, the term 'ulama' has various names. For example, there are titles called Kiai (Java), Tengku (Aceh), Ajengan (Sundanese), Buya (Minangkabau), Sheikh (North Sumatra), Tuan Guru (Lombok NTB, Kal faith in South and Central Kalimantan ).

Talking about ulama in Indonesia is not something new. The reason is that this has been studied and researched by Indonesian Islamic academics and observers. Both from the insiders and outsiders. However, because the problem of the ulama is not something that is final but it is continually proceeding along with the movements and dynamics of the era, in fact, right when this topic is reviewed again to take its elanvital.

\section{B. Understanding Ulema in Islam}

Muhammad Chirzin in his article "Ulama and Umara Perspective alQur'an", explains the definition of scholars from Arabic in the form of plural, namely alim. That is, knowledgeable, and intelligent people. In the Big Indonesian Dictionary (Kamus Besar Bahasa Indonesia), ulama are interpreted as people who are experts in the knowledge of the Islamic religion. In its development, the definition of ulama continues to experience significant changes. Etymologically, ulama interpreted as the leaders of religion or religious leaders are tasked to protect, nurture and guide the people of Islam both in matters of religion or everyday problems that required both from the religious and social. ${ }^{4}$

In the al-Qur'an, the term/ word of the ulama is mentioned in two, firstly it is in the letter ash-Syu'ara verse 197 and secondly, it is in the letter al-Fatir verse 28 . In this case, to get a comprehensive understanding of the ulama the author bases in verses that directly refer to the word ulama or not, like only QS. az-Zumar verse 9, surah Ali Imron verse 164, surah alBaqarah 151 and others.

In formulating its relation to the concept of scholars, the writer divides it into four categories, namely characteristics, position, tasks, and virtues of scholars. When M. Quraish Shihab explained the character of ulama, he based it on two verses, namely QS. ash-Syuara verse 197 and al-Fatir verse 28. M. Quraish Shihab explains that the word of ulama contained in the ash-Syu'ara verse 97 is taken from the word älima (one who knows).

4 Zaenal Abidin Bagir, Ilmu, Etika, dan Agama: Menyibak Tabir Alam, Manusia, dan Etika. Yogyakarta: CRCS-UGM, 2006. 
According to Quraish Shihab, knowledge here is that people who know the Qur'an and are not limited to Muslims, whoever has that knowledge, he is the so-called ulama. This is because M. Quraish Shihab in interpreting the verse pays attention to the context of the verse that came down at that time ie those of the Children of Israel knew about the nature of the Qur'an as a revelation of God and the truth of the qualities it bears because it is in accordance with what they know through their holy $b$ even knowing the truth of their wombs.

M. Quraish Shihab also pays attention to the style of language or vocabulary and munāsabah verses, that is, the relationship with the previous or after verse. This is seen when he interprets the word ulama, which is someone who knows about the Koran, this is because the previous verse explains the Qur'an and the Prophet Muhammad which have been mentioned in previous books such as only the Gospel, Zabur, Torat.The People do not want to learn her and also resist the truth in the book of the Koran and the Prophet Muhammad. Even though the Bani Israel cleric knew the case.

Interestingly, M. Quraish Shihab has a different view when interpreting the second verse of Surah al-Fatir verse 28. In his statement, in this verse, the ulama is someone who knows, both related to religious knowledge or natural phenomena, and with his knowledge delivering himself Khasyah (having a sense fear) of Allah. Khasyah is meant here according to the expert of the language of the Koran, ar- Raghỉb alAshfăhănī is fear accompanied by respect born from the knowledge of the object. The revelation in the Koran that those who possess these characteristics are only scholars, means that those who do not possess them are not scholars.

The interpretation of M. Quraish Shihab to the second verse is certainly different, that is, if the first verse refers to the word ulama only those who know the Qur'an, then the second verse has a broader scope. M. Quraish Shihab interprets Surah al-Fatir verse 28, which is by referring to the root word of the cleric which is the plural form of the word allim which means (to know clearly). Therefore, all words formed by the letters ain, lam, mim always refer to clarity, such as' nature/flag, nature/universe being that has a taste and or intelligence, alămah/ address.

M. Quraish Shihab also added the verses munassabah as a support to interpret it as explained in the previous paragraph (surah al-Fatir [35] verse 27 ) that the Koran alludes to natural phenomena, which includes the process of reducing rain, and from the rain growing - plants will produce fruits of various kinds, as well as a diversity of depictions of mountains. Hence it is, M. Quraish Shihab informed that knowledge of natural 
phenomena is so important and if among us have knowledge relating to natural phenomena in and with knowledge drove him fear Allah, then that person can be said to scholars.

In socio-political dynamics of the role and position of the clergy, in today's context, shifting and changing the meaning. It is not wrong to say that the role of scholars is more complex compared to scholars in previous periods. Likewise, when viewed from the background of religious thought, ideology, and understanding, contemporary Indonesian scholars also have different ideological typologies that should be understood together.

From this, discussing contemporary Indonesian ulama cannot be separated from the intellectual social history of ulama from time to time. Azyumardi Azra gave an important note that the history of the origin and development of ulama in the archipelago was strongly influenced by the Middle Eastern ulama network. According to Azra, scholars in Indonesia are part of a network of links between Islam in the Arab region and Indonesia.

Citing opinion AZR Azyumardi that $\mathrm{h}$ an association of Muslim archipelago and the Middle East are connected since Islam developed in the archipelago. Based on Azyumardi Azra's study, the relationship is political and scientific. Political relations existed between several kingdoms in the archipelago with the Ottomans. It was noted that Aceh, Banten, Mataram, had sent messengers to Haramain (Mecca-Medina) since the 17th century. In addition to hajj, they also brought the sultan's title from Syarif Mecca (ruler of Mecca). Could be a strengthened authority over their power. But there is also a scientific relationship. ${ }^{5}$ Since the Ottomans secured the pilgrimage route, more and more people were studying in the 14th to 15th centuries. That is what drives the emergence of the Jawi community. The Arabs call it ashab Al Jawiyin (our brother is Jawi). Jawi originated from Java. Jawi community to refer to people who come from the Archipelago (even Southeast Asia). The names of scholars such as Sheikh Yusuf Al- Makassary (Makassar) and Sheikh Abdul Rauf Al-Sinkili (Singkel, Aceh), were poor scholars who studied in Haramain in the 17th century.

\section{The Role of Ulema in Contemporary Indonesia}

Globally, the role and position of Indonesian ulama are huge. Azyumardi Azra once noted that scholars in Indonesia played a major role in the social life of the people. Scholars are directly related to the political

5 Syaifuddin, Anggraeni, Khotimah, Mahfud, C. "Sejarah Sosial Pendidikan Islam Modern di Muhammadiyah". Tadarus, 8 (1) 2019. 
structure. They established a relationship which, in Max Weber's terms, was a patron-client relationship: ruler as patron and cleric as the client (patronage).

Yudi Latif in the book "Muslim Intelligence and Power" also provides a critical note on the ulama's socio-political role which is enormous for the development of a public socio-political system that is in line with Indonesian Islamic values. Silfia Hanani also explained the role of ulemas in several regions of Indonesia, especially in Minangkabau. According to Hanani, ulemas in Minangkabau are not just religious symbols. But also as an agent of movement. In Minangkabau, ulama and religious leaders are the highest statuses in society. In this context, the ulama is a role model, which is very influential on the social movements of society. ${ }^{6}$

In this context, ulama play an important role in a country. Its existence is always a reference for consultations by the government and prospective leaders. In Indonesia, the Sowan culture is commonly practiced by state officials or party leaders, especially ahead of regional head and presidential elections. In the history of Islamic civilization, the role of the ulema also occupies a very important position. For example in the days of the Companions, the ulema had the function of being the heirs of prophets and guards of the prophetic mission. Imam Al Ghazali placed the position of ulama as guardians of religious authority. Al-Ghazali's theory in the book of Ihya Ulumuddin explained that the bad people were caused by the ruler who was also bad. While bad rulers are caused by bad clerics. According to al Ghazali, because of the badness of an ulama when he loved wealth and position. Though the real task of them is the guardian of religion, control and advise the authorities.

In the colonial era, the ulama in Indonesia had a big role behind all of that. Resistance against the invaders became a jihad for fighters at that time. They are not fighting for their person or group, but they are fighting for the country because of God. That's what fighters like Trunojoyo, Sultan Nuku, Diponegoro, Imam Bonjol, and other fighters do. It is also the ulema who can unite this vast territory of Indonesia. The varied nature and culture of Indonesia is a challenge for scholars to unite. I slam organization was very influential in the national revival movement at that time. Through Sarekat Islam, the struggle against the colonialists as an organization had begun, even long before Budi Utomo was established.

In the context of contemporary Indonesia, ulama campaigned for wasathiyah Islam as an Islam where the ulama and the ummah truly

'A Amrizal, "Dimensi Sufistik Dalam Pandangan Hidup Orang Melayu". Akademika: Jurnal Pemikiran Islam, 21(2) (2016): 275-290. 
present a life that produces a virtue of goodness, not only in the afterlife but also in the world. It is not only the common good but also the good which brings changes that lead to excellence. ${ }^{7}$

Today, the problem of communities is also the responsibility of ulama. The complexity of the problem demands that the role of the ulema become more active and broad. For example, the role of scholars to understand and respond in the case of HIV AIDS. Website Kesrepro.info informs that HIV and AIDS not only touches the health level but also goes into all fields including matters of faith or religion. Many people who have minimal understanding and wrong understanding of HIV/ AIDS cause the disease to be a source of stigma and discrimination. Not to mention the notion that $\mathrm{HIV} / \mathrm{AIDS}$ is considered a curse and God's punishment and is associated with one's morals.

Seeing the above facts, Syafiq A. Mughni, a lecturer at UIN Sunan Ampel Surabaya, explained that a good strategy for tackling HIV \& AIDS is to revitalize the role of religion as a way of life, including human relations. Practically, said Syafiq, community and religious leaders at the village or sub-district level occupy a very central position because they live daily with the community. The cleric used to be a reference in solving various problems in the community. If they are made aware and provided with adequate knowledge about HIV \& AIDS, they will certainly be effective agents for preventing the spread of the virus and reducing stigma and discrimination.

Furthermore, Syafiq explained that religious leaders, for example, ulama, had permanent media to enlighten the public. They have become accustomed to filling sermons in the mosque every Friday and filling in the taklim prayer regularly. With a religious approach, Ulama can become a "policy champion" in overcoming HIV \& AIDS. Seeing the great role of clerics, leaders and religious leaders in influencing society, they need to be equipped with information about sexually transmitted infections (STIs) and HIV/ AIDS correctly. With true understanding, it will spread true understanding as well. Conversely, when misunderstanding and having a misunderstanding, it is inevitable to spread wrong and wrong understandings, which certainly should be minimized early on.

The face of Indonesian Islamic cleric contemporary is not monolithic, therefore, for a more comprehensive understanding of scholars today, so I

7 Thomas B. Pepinsky, R. William Liddle, and Saiful Mujani. Piety and Public Opinion: Understanding Indonesian Islam. Oxford: Oxford University Press, 2018. Also, Robert Spencer. The Politically Incorrect Guide to Islam (and the Crusades). Regnery Publishing, 2005. 
tried to create an alternative path that can be taken to make typology. In general, Ulama in contemporary Indonesia could be understood in the typology ideology-praxis, the following: First, typology Ideological. Ideologically, typologies of contemporary Indonesian scholars, namely: Radical Ulama, Moderate Ulama, and Cosmopolitan Ulama. Radical Ulema is a term for Muslim scholars and figures who have radical views and ideologies. Meanwhile, moderate Ulama is an ulama whose thoughts and outlook on life tend to be more moderate. Meanwhile, scholars Cosmopolitan that scholars tend to think and act in global as well as local. Abdurrahman Wahid noted that cosmopolitanism in Islamic civilization consisted of several dominant elements in it, such as the loss of ethnic boundaries, strong cultural plurality, and political heterogeneity. Cosmopolitan itself present an apparition in the dominant element, namely the religious life electrocautery tick for centuries. ${ }^{8}$

Second, the practice of praxis. In praxis- movement, typologies of contemporary Indonesian scholars can be classified, namely: Traditional Ulema, Professional Ulema, and Organizational Ulama. The term traditional and organic ulama is borrowed from the term used by Antonio Gramsci who refers to traditional and organic intellectuals, because of the position and role of an intellectual. In this context, traditional ulama are intended to refer to ulama figures who are only concerned with personal or group interests. While professional scholars refer to their respective professions. For example, there are professional missionary clerics on television, professional scholars on campus, professional scholars of doctors, and so forth. Meanwhile, organic ulama is a figure of ulama who plays a role in all aspects of religious and state life by upholding idealism for the sake of virtue, justice, and goodness. ${ }^{9}$

All typology of ulama, academically, helps our understanding that scholars in contemporary Indonesia have a vital role and contribution also varies. All that needs to be understood comprehensively about the role of the ulama in contemporary Indonesia, especially in shaping imagined

8 K. Aljunied, Hamka and Islam: Cosmopolitan Reform in the Malay World, USA: Cornell University Press, 2018.

9 Choirul Mahfud, "Evaluation of Islamic Education Curriculum Policy in Indonesia". Premiere Educandum: Jurnal Pendidikan Dasar dan Pembelajaran, 9 (1) 2019: 34-43. Also, Choirul Mahfud, "The Genealogy of Social History of Islamic Education Politics In Indonesia". Al-Tadzkiyyah: Jurnal Pendidikan Islam, 10 (1) 2019: $1-12$. 
Islamic societies such as Nusantara Islam, moderate Islam, progressive Islam, and Islam Rahmatan Lil Alamiin. ${ }^{10}$

\section{Conclusion}

For a long time in contemporary Indonesia, it can be understood in its role and contribution that is characterized by ideological-praxis in shaping an imagined Islamic society. The community can be called the Nusantara Islamic community, progressive Islam or moderate Islam. In general, Islamic ulama in Indonesia are also part of cosmopolitan scholars, those who tend to think and act globally as well as locally. However, there are also Indonesian Ulema who are traditional, and professional. The term traditional and organic ulama is borrowed from the term used by Antonio Gramsci who refers to traditional and organic intellectuals, because of the position and role of an intellectual. In this context, traditional ulama are intended to refer to ulama figures who are only concerned with personal or group interests. While professional scholars refer to his profession which has to do with clergy. Whereas organic ulama are figures of scholars who play a role in all aspects of religious and state life by upholding idealism for the goodness[.]

\section{REFERENCES}

Azra, A. "Kesalehan dan Politik: Islam Indonesia". Studia Islamika, 25(3)2018: 639-650.

Aljunied, K.Hamka and Islam: Cosmopolitan Reform in the Malay World, USA: Cornell University Press, 2018.

Amrizal, A. "Dimensi Sufistik Dalam Pandangan Hidup Orang Melayu". Akademika: Jurnal Pemikiran Islam, 21(2) (2016): 275-290.

Bagir, Zaenal Abidin, Ilmu, Etika, dan Agama: Menyibak Tabir Alam, Manusia, dan Etika. Yogyakarta: CRCS-UGM, 2006.

Fathurahman, O. “Jaringan Ulama: Pembaharuan dan Rekonsiliasi dalam Tradisi Intelektual Islam di Dunia Melayu-Indonesia". Studia Islamika, 11(2)2004.

Gramsci, Antonio. Selection from the Prison Notebooks. New York: International Publisher, 1971.

Hassan, Riaz. Faithlines: Muslim Conceptions of Islam and Society. Oxford: Oxford University Press, 2003.

Jahja Omar, Toha, Ilmu Dakwah, Jakarta: Widjaya, 1992.

${ }^{10}$ I. Mustofa, "Sketsa Pemikiran Islam Liberal di Indonesia". Akademika: Jurnal Pemikiran Islam, 17(2) (2012): 153-176. 
Jamhari, "New Trend of Islamic Education in Indonesia," Studia Islamika, Vol 16, No 2, (2009).

Krisdiyanto, Muflikha, Sahara, Mahfud, C., "Sistem Pendidikan Pesantren dan Tantangan Modernitas". Tarbawi: Jurnal Ilmu Pendidikan, 15 (1), 2019: 11-21.

Maarif, Ahmad Syafii, Pengkhianatan Kaum Intelektual Indonesia: Perspektif Kebudayaan, Naskah Pidato Kebudayaan, 22 November 2005, di Graha Bhakti Budaya-Taman Ismail Marzuki, Jakarta.

Mahfud, Choirul. "The Role of Cheng Ho Mosque: The New Silk Road, Indonesia-China Relations in Islamic Cultural Identity". Journal of Indonesian Islam, 8 (1) 2014: 23-38.

. "Evaluation of Islamic Education Curriculum Policy in Indonesia". Premiere Educandum: Jurnal Pendidikan Dasar dan Pembelajaran, 9 (1)2019: 34-43.

. "The Genealogy of Social History of Islamic Education

Politics In Indonesia". Al-Tadzkiyyah: Jurnal Pendidikan Islam, 10 (1) 2019: 1-12.

Mustofa, I. “Sketsa Pemikiran Islam Liberal di Indonesia”. Akademika: Jurnal Pemikiran Islam, 17(2)(2012): 153-176.

Pepinsky, Thomas B., R. William Liddle, and Saiful Mujani. Piety and Public Opinion: Understanding Indonesian Islam. Oxford: Oxford University Press, 2018.

Sales, Arnaud dan Fournier, Marcel (ed.), Knowledge, Communication and Creativity, London:SAGE, 2007.

Syaifuddin, Anggraeni, Khotimah, Mahfud, C. “Sejarah Sosial Pendidikan Islam Modern di Muhammadiyah". Tadarus,8 (1)2019. 